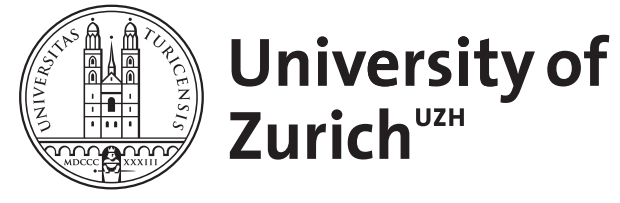

\title{
The quotative marker in Gilaki
}

\author{
Völlmin, Sascha
}

\begin{abstract}
Gilaki belongs to the Caspian subgroup of Northwest Iranian and can be divided into two major dialect groups, Western Gilaki with Rasht as its center and Eastern Gilaki with Lahijan as its center (Stilo 2001: 660). There are between two and three million speakers, most of whom are bilingual in Gilaki and Persian. The following is a first presentation of reported speech in Gilaki or, more exactly, the quotative marker in Rashti, i.e., the Western Gilaki dialect of the city of Rasht. The language data used in this chapter derive from a corpus of about thirty minutes of audio recordings of natural speech and dialogues or spontaneously narrated stories of Gilaki speakers raised in (or around) Rasht. Thus, the results presented here hold true only for Rashti for certain. The situation in other Western Gilaki variants or Eastern Gilaki must be left open. However, concluding from a remark of a speaker of Eastern Gilaki saying that "people in Rasht speak like this" (i.e., with the quotative marker), it is possible that no (or no similar) quotative marker exists in Eastern Gilaki. There are not many sources available that describe Gilaki, and no descriptions of reported speech in this language, a topic often neglected in grammars. The most comprehensive grammar (Rastorgeuva et al. 1971) and the most recent (but short) description by Stilo (2001) do not treat reported speech; likewise Sartippur (1990). This chapter intends to be a contribution to fill this gap. On the other hand, however, I also hope to show that Gilaki exhibits typologically interesting features with regard to reported speech in general as well as in Iranian languages in particular.
\end{abstract}

DOI: https://doi.org/10.1515/9783110604443-008

Posted at the Zurich Open Repository and Archive, University of Zurich

ZORA URL: https://doi.org/10.5167/uzh-176912

Book Section

Published Version

Originally published at:

Völlmin, Sascha (2019). The quotative marker in Gilaki. In: Korangy, Alireza; Mahmoodi-Bakhtiari, Behrooz. Essays on Typology of Iranian Languages. Berlin, Boston: De Gruyter, 133-148.

DOI: https://doi.org/10.1515/9783110604443-008 


\section{The quotative marker in Gilaki}

Gilaki belongs to the Caspian subgroup of Northwest Iranian and can be divided into two major dialect groups, Western Gilaki with Rasht as its center and Eastern Gilaki with Lahijan as its center (Stilo 2001: 660). There are between two and three million speakers, most of whom are bilingual in Gilaki and Persian. ${ }^{1}$

The following is a first presentation of reported speech in Gilaki or, more exactly, the quotative marker in Rashti, i.e., the Western Gilaki dialect of the city of Rasht. The language data used in this chapter derive from a corpus of about thirty minutes of audio recordings of natural speech and dialogues or spontaneously narrated stories of Gilaki speakers raised in (or around) Rasht. Thus, the results presented here hold true only for Rashti for certain. The situation in other Western Gilaki variants or Eastern Gilaki must be left open. However, concluding from a remark of a speaker of Eastern Gilaki saying that "people in Rasht speak like this" (i.e., with the quotative marker), it is possible that no (or no similar) quotative marker exists in Eastern Gilaki.

There are not many sources available that describe Gilaki, and no descriptions of reported speech in this language, a topic often neglected in grammars. The most comprehensive grammar (Rastorgeuva et al. 1971) and the most recent (but short) description by Stilo (2001) do not treat reported speech; likewise Sartippur (1990). This chapter intends to be a contribution to fill this gap. On the other hand, however, I also hope to show that Gilaki exhibits typologically interesting features with regard to reported speech in general as well as in Iranian languages in particular.

\section{Reported speech in general and in the region}

There are two ways to report speech: direct and indirect. Generally speaking, direct speech is the unchanged quotation of an utterance, whereas indirect speech is the repetition of an utterance with shift of the deictic center from the reported speech situation to the actual speech situation. This involves in

1 Different degrees of mastery of both Gilaki and Persian can be found. Nowadays (at least in Rasht and presumably also in other towns) children are often raised only in Persian. As a result, many are semi-speakers or have only passive command of Gilaki. Cf., e.g., Pakpour (2015: 19). 
particular the pronouns. Depending on the language, additional changes as, for example, the TAM-forms or the choice of the complementizer may be required for indirect speech. ${ }^{2}$

When dealing with reported speech in European languages, a main issue often is which of these changes are necessary in indirect speech. For the languages in and around Iran, however, this question is rather secondary. In this area, the more usual way to report an utterance is the use of direct speech. Indirect speech may be possible, but in general it is not often employed or may, for example, be limited to higher registers such as the literary language. This situation is reported for Kurdish by Akin (2002: 79). In his corpus indirect speech is very rare and appears, if at all, only in written language. The same holds true for Caucasian languages such as Georgian and Abkhaz: according to Hewitt and Crisp (1986), there is a great preference for direct speech to indirect speech. In Persian, the situation seems to be a little less clear-cut. Nevertheless, according to Alavi and Lorenz (1994: 239), as well as to my own intuition, Persian "exhibits a reluctance" toward indirect speech. The direct method appears to be the more natural way of reporting speech.

Gilaki does not differ in this respect from these languages. In the corpus used for this chapter, virtually no instances of indirect speech are found. Direct speech, i.e., the quotation of an utterance without shifting the deictic center, is definitely the preferred way to report speech. There is, however, a small but essential difference that distinguishes Gilaki (or at least Rashti) from Persian and other Iranian languages and makes it typologically outstanding: the marker -ə. Due to its primary use to mark the verbs in quoted utterances, it is best named the “quotative marker". It will therefore be glossed as QUOT in the examples.

The following sections describe the form as well as the basic and secondary functions of the quotative marker in more detail. Finally, a possible origin of -ə is proposed.

2 German, for example, has a shift in mood (from indicative to subjunctive) and tense (from present to past; especially to avoid ambiguous forms). In addition, the choice of the complementizer (no complementizer possible with direct speech) and word order change (from verb second to verb final as a characteristic of German dependent clauses) can distinguish indirect from direct speech (Coulmas 1986: 14-21). 


\section{The quotative marker -a}

In Rastorgueva (1971), instead of the proper personal ending of the first person singular -əm, occasionally a variant -əmə is found. Some paradigms (p. 147) might suggest that -əmə is an allomorph in the present tense and subjunctive, but at large the distribution is completely random and no explanations of its function are given there. These few examples of an extra - $\partial$ after -əm are the only traces of the quotative marker in the available sources.

In my corpus, however, there are over two hundred instances of an -ə added to the personal ending of a verb. As Table 1 shows, this is not restricted to first person or present tense, but is possible in virtually all persons and TAM-forms:

Table 1: Examples for verb forms with -ə.

\begin{tabular}{|c|c|c|c|c|c|c|}
\hline & Present & Subjunctive & Imperative & Past & Imperfect & Past perfect \\
\hline $1 \mathrm{SG}$ & bər-əm-ə & bu-kun-əm-ə & - & bu-kud-əm-ə & na-nast-i-m-a & \\
\hline $2 \mathrm{sG}$ & dan-i-ə & bа-ха-i-ə & bu-kun-ə & bu-kud-i-ə & & \\
\hline $3 \mathrm{SG}$ & kun-e-yə & bа-b-ว-уә & - & $b$-amo-yə & Šo-i-a & $b \partial-k \partial f t a-b u-y \partial$ \\
\hline $1 \mathrm{PL}$ & isa-imi-a & $b$-avar-imi-a & - & & & \\
\hline $2 \mathrm{PL}$ & dar-idi-ə & bi-g-idi-a & bu-kun-idi-ə & & & \\
\hline $3 P L$ & kun-idi-ə & & - & & fukud-i-d-a & \\
\hline
\end{tabular}

The forms listed above are actual data from the corpus. The blank fields do not represent impossible forms; rather, they are simply not found in the corpus by chance. As for the transcription of the quotative marker after vowels, I have chosen the following convention: - - after $i$, -ya after all other vowels.

I will not discuss the verbal system of Gilaki here. ${ }^{3}$ The important point for this chapter is that - 2 can be added to every single (conjugated) verb form, regardless of its person, tense, or aspect, including even the imperative. There is only one crucial exception (or "special case"), which will be discussed in Section 7: the third person singular of the past.

3 Consider, though, the following general remarks: no special tense-aspect-modality marker for present; imperfect has a suffix -i; subjunctive/imperative, past and past perfect have a prefix ba-. $b$ ə- is suppressed (a) with the negation nə-, (b) when the verb root already has a preverb, (c) after the change-of-state marker $-a$. 


\section{Basic pattern: Occurrence of -a after goftan 'say'}

The by far most frequent occurrence of verb forms with an additional -ə is in complement clauses of gofton 'say', normally (but not necessarily) with the subordinator ke. Example (1) represents a prototypical sentence for the use of -ə:

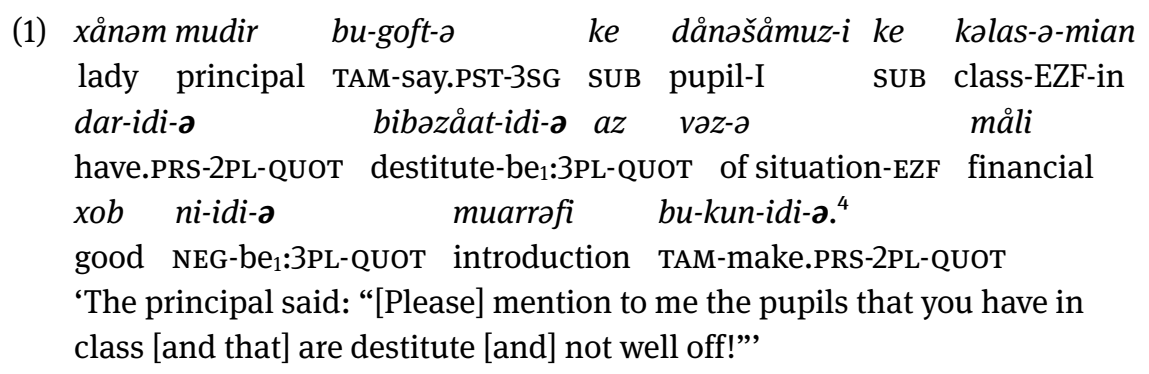

The speaker introduces her narration with xånəm mudir bugofta 'the principal said'. After the subordinator $k e$ she repeats what the principal had once said to her. Every single verb following bugofta ke 'said that' is marked with -ə: a present (dar-idi-a), a positive (-idi-ə), and a negative copula (ni-idi-ə), as well as an imperative $^{5}$ (bu-kun-idi-ə). Apart from the introductory verb and the subordinator, the only difference between this reported speech and a (non-reported) direct speech is the existence of the added -ə. Therefore the (reconstructed) original sentence quoted in (1) must have been as the following:

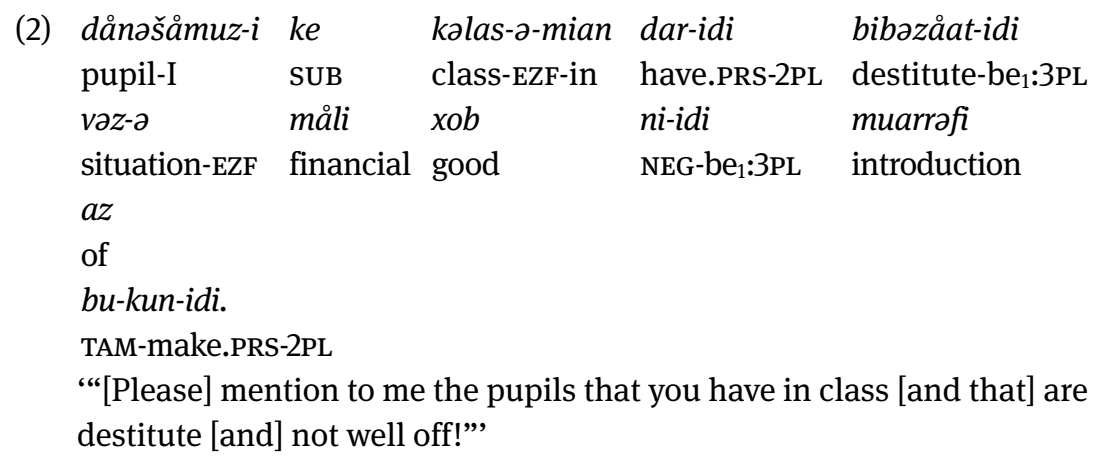

\footnotetext{
4 The use of -idi may be confusing. This suffix is the enclitic copula and the personal ending of the verbal paradigms of both second and third person plural.

5 This form could as well be interpreted as a subjunctive with optative meaning.
} 
In (1) the quoted sentence is a first-hand report, i.e., the original utterance was directed toward the speaker of (1). This, however, is not a prerequisite for the use of -ə. The reported information can also be second-hand or third-hand:

(3) $M$

$\begin{array}{lllll}\text { Mi } & \text { mår } & \text { tarif } & k u d-i & k e, \\ \text { 1sG.Poss } & \text { mother } & \text { description } & \text { make.PST-IPFV:3SG } & \text { SUB } \\ \text { goft-i } & & k e, \quad i-t a & & \end{array}$

say.PST-IPFV:3SG SUB one-CLF

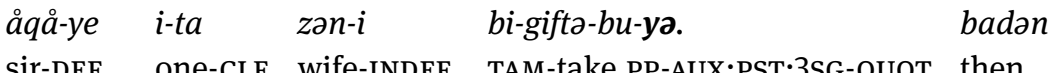

Sir-DEF
ani
xånวvåda

3SG.Poss family

tarif kud-i-ə ke an zamån-i ke kučik

description make.PST-IPFV:3SG-QUOT SUB 3SG time-I SUB little

bu-yə

be .PST:3SG-QUOT

bə-kəftə-bu-yə ani pišåni

TAM-fall.PP-AUX:PST:3SG-QUOT 3SG.POSS forehead

bə-škวstว-bu-yə. ${ }^{6}$

TAM-break.PP-AUX:PST:3SG-QUOT

'My mother used to tell (and she used to say) that a man had gotten married (lit. had taken a woman). (Then) his family used to tell that when he was little he had fallen down [and] his forehead had broken'.

Here, the speaker reports what her mother used to tell her. The first two verbs after the introducing verbs of saying are the mother's words (bi-giftə-bu-yə 'he had taken' / tarif kud-i-a 'she used to tell'). The following verbs (bu-yə 'he was'/ bə-kəftə-bu-yə 'he had fallen' / bə-škəstə-bu-yə 'it had broken'), however, are not her mother's words but “his family's”, i.e., a third person's. Nevertheless, all verbs are marked equally with -ə (and only one -ə). Thus, the source of the utterance is not important. Rather, - $\partial$ indicates that the utterance is not of the actual speaker, but so to speak out of somebody else's mouth. The same holds true in the following example:

6 The use of past perfect is not (necessarily) a shift of tense to indicate anteriority. In Iranian languages, the past perfect is much more common than, for example, in English, so it can have been used in the original speech as well. 
(4) bu-gu agar qarår bə-b-ว-yə ke un Məhin-a TAM-say.PRS if agreement TAM-be $1 . P R S-3 S G-Q U O T$ SUB 3SG Mahin-OBJ rəvån-a kun-ə-yə, bə- $d-\partial^{7} \quad$ Mahin xu-re tanhå going-CS make.PRS-2SG-QUOT TAM-give.PRS-3SG Mahin self-for alone bə-ร̌-ว-yə.

TAM-go.PRS-3SG-QUOT

'Say [to her]: "If it is agreed that he should send Mahin [on a voyage], let Mahin go all by herself”,.

Here again, the sentence following the introducing imperative bugu 'say' is not what the speaker actually says to the hearer, but what the hearer is supposed to say to somebody else (in the future). This example makes it clear that -a indeed is a quotative marker, as it not only occurs when reporting previously pronounced utterances, but rather in all sentences that do not constitute an actual (or original) direct speech. Thus, every time you say the words of someone else, be it a real report or a speech that has not yet happened, the quotative marker is used.

To recapitulate so far, Gilaki (Rashti) possesses a quotative marker - $\partial$, which is added to every single verb in quoted sentences. This is the usual method to report speech in this language. Remember that these quotations (and therefore reported speech) do not involve any shift of the deictic center: the personal pronouns and endings stay the same as they are in the original sentence. One effect of this system is that in reported speech you can say "I", "me", or "my" without referring to yourself, or on the other hand say "you" or "your" without meaning the person you are speaking with. Yet no confusion arises. Since the verbs of the quotations are marked with - $\partial$, it will not be understood as actual direct speech. Who exactly you are referring to has to be determined by the context.

In the case of the first person singular, however, there seems to be a certain reluctance to the use of the pronouns man 'I' and mi 'my' in quotations. Although there is no problem to do so - cf. example (7) - this somewhat peculiar situation can be avoided by using the logophoric pronoun $x u$ 'self' instead of both man 'I' (second $x u$ ) and $m i$ 'my' (first and third $x u$ ):

7 For the lack of -ə here, see Section 6 "Absent -ə". 
(5) g-e ke pas tu muvåzab-ə xu zan bu-bu-ya!

say.PRS-3SG SUB so 2SG watching-EZF LOG wife TAM-be..PRS-QUOT

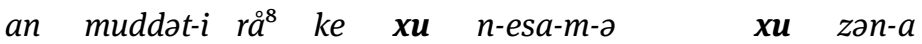

this while-I оBJ SUB LOG NEG-be 3 -1SG-QUOT LOG wife-OBJ

tu kontorol bə-dar-ə!

2SG control TAM-have.PRS-QUOT

'He says: "Thus you look after my wife! When I am not here, you control my wife!"’

The use of $x u$ instead of $m a n / m i$ depends probably only on the speaker: some seem to prefer $x u$, while others rarely use it. ${ }^{9}$ As for the personal endings of the corresponding verbs, note that they are not affected by $x u$, but remain in the first person singular ( $x$ u nesama 'I am not').

\section{4 -a without goftan 'say'}

Quotations are most of the time introduced by goftan 'say' or another verb of saying. This, however, is not a condition for the use of -ə. The introductory verb can also be omitted. The presence of - $\partial$ assures that the sentence is perceived as a quotation. It is thus possible to change between direct (i.e., non-quoted) and quoted speech without announcing it:

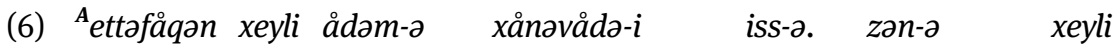
by.the.way very person-EZF family-ADJ/INDEF be 2 -3SG woman-EZF very xob-i-ə. $\quad{ }^{\text {B }}$ təmåm-ə mi labås, raxt, hamə či-a good-INDEF-be 13 SG all-EZF 1SG.POSS clothes laundry all thing-OBJ šor-e-yə.

wash.PRS-3SG-QUOT

'A $\mathrm{By}$ the way, she is a very family-oriented person. She is a very good woman. "'She washes all my clothes, laundry, everything”,

This is an extract of a conversation. First, the speaker makes a personal direct statement about a woman (marked with ${ }^{\mathrm{A}}$ ). Then, he quotes a sentence somebody else said about the same woman (marked with ${ }^{\mathrm{B}}$ ). There is no break

8 rå object (specific-referential) (or maybe the whole structure an muddati rå ke) is Persian.

9 Further testing is needed to determine to which degree and in which contexts $x u$ occurs in a regular pattern, or whether its use is more or less only idiosyncratic. 
between the two parts and no introducing verb of saying. Nevertheless, due to the quotative marker, the hearer can easily distinguish between direct utterance and quoted utterance. It is clear from the context who uttered the quoted sentence originally, the involved person(s) having been introduced earlier in the conversation. As for the first person possessive pronoun $m i$ 'my', recall that this does not point to the actual speaker of (6), but to the original speaker of the quoted sentence.

In the following example, the speaker again switches (without announcing it). This time, however, he does not report a previous utterance:

$\begin{array}{llllll}\text { Aåfarin! } & { }^{B} \text { man } & \text { fikr } & \text { bu-kud-əm-ə } & \text { šime } & \text { sar-a } \\ \text { exactly } & 1 \mathrm{SG} & \text { thought } & \text { TAM-make.PST-1SG-QUOT } & \text { 2PL.POSS } & \text { head-OBJ } \\ \text { kulå } & & & & & \\ \text { hat } & & & & \end{array}$

hat

bə-n-əm-ə. $\quad{ }^{A}$ vali ištวbå kud-ən-dər-ə.

TAM-put.PRS-1SG-QUOT but mistake make-INF-be 4 -3SG

'A Exactly! ${ }^{\mathrm{B}} \mathrm{He}$ thought that he could trick us [lit. put a hat on us]. ${ }^{\mathrm{A}} \mathrm{But}$ he is making

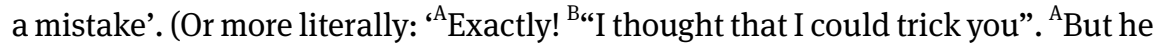
is making a mistake'.)

After the reply to somebody else's comment with åforin 'exactly', there is a "quoted" sentence $\left({ }^{B}\right)$, which is completely imagined. Certainly it was never uttered this way. Rather it expresses what the speaker assumes somebody else might have thought or intended. To verbalize this assumption, he pretends that the other person had actually said it and employs the quotative marker to "quote" them. Finally, he adds his own comment, switching back to direct speech. Again, consider the different deictic centers: the first person subject in ${ }^{\mathrm{B}}$ points to the same extra-linguistic person as the third person in ${ }^{A}$. Note also that the possessive pronoun šime 'your' is pointing to the speaker himself (and others).

\section{5 -a after verbs of cognition}

The marker - $-\partial$ is labeled a quotative marker because of its predominant use in quoted sentences. However, there is an occasional extended use after verbs of cognition in general such as fikr kudən 'think' (8) and mutəvajjah bostan 'realize, become aware' (9). 
(8) man hamišə fikr kud-i-m ke Banəfร̌ə bə

1SG always thought make.PST-IPFV-1SG SUB Banafsheh to

råh-ə dur-i ř-e-yə.

way-EZF far-INDEF go.PRS-3SG-QUOT

'I always thought that Banafsheh would go far away'.

(9) mutəvajjah ni-b-idi ke Piruz Rəšt-i-ə-yə.

attentive NEG-become.PRS-3PL SUB Piruz Rasht-ADJ-be 1 :3SG-QUOT

'They did not realize that Piruz is a Rashti (=from the town of Rasht)'.

The difference to proper quotations is not as significant as it may seem, especially since thoughts can be regarded as communication with yourself, so when expressing them you quote yourself in a way. Nevertheless, this is in contrast to "real" quotations of oneself - cf. examples (10) and (11).

\section{Absent -a}

Until now, -ə has been presented as an obligatory marker for all verbs in all quotations. But, as a matter of fact, it is sometimes also absent.

When quoting oneself, -ə is not present:
bu-šu.
TAM-go.PRS
(10) bu-goft-am
tu $x a-i$
$b i-\check{s}-i$,
Faxri-amara
TAM-say.PST-1SG 2SG want.PRS-2SG TAM-go.PRS-2SG Fakhri-with
'I said: “If you want to go, go with Fakhri”'.

This is not limited to the first person singular, but also applies to the first person plural:
(11) bu-goft-im
agว ato-yə
tu $\quad t i$
TAM-say.PST-1PL if like.this-be1:3SG 2SG 2SG.POSS
bår-o-kuč- $a$
usan
load-and-household-oBJ pick.up.PRs
b-avar ame xåna.
TAM-bring.PRS 1PL.POSS house

'We said: "If it is like this, take your things [and] bring [them] to our house"”. 
This is the reverse of the above characterization of the quotative marker, saying that -ə indicates that "the uttered sentence is out of somebody else's mouth"; thus, when quoting oneself, the uttered sentence is not out of somebody else's mouth. Consequently, -ə is not present, even though the sentence is not an actual utterance, but a quotation.

The invariable modals, in particular båyəd ${ }^{10}$ 'must', cannot take -ə:
bu-goft-a
man čəra
båyəd təra
bว-šnas-วm-ə?
TAM-say.PST-3s
$1 \mathrm{SG}$
why must
2SG.OB
TAM-know.PRS-1SG-QUOT
'He said: "Why do I have to know you?",

Also, the inflected modal verbs quite often do not have the quotative marker as, for example, xastan 'want'; see also bədə 'let' in example (4):

ama xa-im kumək ašan-a bu-kun-imi-ə.

1PL want.PRS-1PL help 3PL-OBJ TAM-make.PRS-1PL-QUOT

'[She said:] "We want to help them", ${ }^{11}$

In addition to the modals, it occasionally happens that one does not affix - -2 to every verb of the quotation, although it would be expected. I find it too difficult to determine any rules for omitting -ə. It seems to be rather random than systematic. For now, it suffices to state that -ə can also be missing every now and then without apparent reason.

\section{The quotative marker and third person singular past}

A somewhat anomalous situation is found in the third person singular of the past. To form the past, you need the past stem. There are past stems ending in consonants and past stems ending in vowels. After a consonant, the regular personal ending of the past is -ə. In this case, it is not possible to affix an additional -ə to mark the quotation:
(14) bu-goft-ə
čəra? åqå-jån či bu-kud-ə-ø
magว?
TAM-say.PST-3SG why sir-soul what TAM-make.PST-3SG-QUOT PART
'She said: "Why? What has he (lit. dear sir) done?"'

10 båy d is a loan from Persian, but much more frequently used than the proper Gilaki $b a / v a$.

11 This is the continuation of example (1). 
If the past stem ends in a vowel, however, the personal ending -ə is always missing. In exchange, the quotative marker can be added:
(15) Raza g-e
dai fada-ø-yə
Amir-a.
Reza say.PRS-3sg uncle give.PST-3SG-QUOT Amir-OBJ
'Reza says: "The uncle gave [it] to Amir”'.

It seems that the - $\partial$ of the quotation is elided after the personal ending -ə. This could be perfectly conceivable. On the other hand, however, the third person singular of the subjunctive (16) and the copula (17) are also -ə, but in these two cases the quotative marker -ə does not disappear:

agar qarår $\quad$ bə- $b$-ə-yə
if $\quad .$.
"“If it is agreed ...”

(17)
bu-goft-a [...]
xob-ə-yว $[\ldots]$
masalə-i
ni-ว-yว.
TAM-Say.PST-3SG good-be 1 :3SG-QUOT problem-INDEF NEG-be 1 :3SG-QUOT
'He said: “That's fine, that's no problem”'.

Apparently, the personal ending of the past differs (in behavior) somehow from the subjunctive and the copula, although they all are -ə (in Western Gilaki). This hypothesis is also supported by data from Eastern Gilaki, where the third person singular in the past is - $\partial$, too, but in the subjunctive $-I$ (Stilo 2001: 661). In any case, it is not possible to add the quotative marker - $\partial$ to the third person singular - $\partial$ of the past. The probable solution for this "special case" could be found in a shared origin of both morphemes. This would explain the fact that they cannot appear together. The copula and the ending of the subjunctive, on the contrary, presumably originate somewhere else, and thus can be combined with the quotative marker - $\partial$.

In this context, a glance at (colloquial) Persian might be helpful. In Persian the past does not have a personal ending in the third person singular (i.e., - $\varnothing$ ). To express evidentiality (and also indirect speech as a subcategory of evidentiality) the perfect is used (cf., e.g., Jahani 2000), which is built with the past participle + auxiliary. In the third person singular the auxiliary is dropped. As a consequence, the verb form looks exactly like the participle, which ends in -e. (In all other persons this - $e$ is elided by the following auxiliary/personal ending; only the stress remains on the last syllable.) Thus, one can reanalyze $-e$ as the personal ending, or, alternatively, as the marker for evidentiality. As a matter of fact, in colloquial Persian it is in principle possible for all third person singular forms that are built on the basis of the past stem to carry this morpheme - $e$ to mark evidentiality: 
(18) Persian

$\begin{aligned} & \text { Mariam be man mi-g-e } \\ & \text { Mariam to 1SG }\end{aligned}$ IPFV-say.PRS-3SG SUB when
$\begin{aligned} & \text { dåšt-e harf } \\ & \text { have.PST-E letter }\end{aligned}$ IPF-zad-e yedaf'e sedå qat
$\begin{aligned} & \text { shod-e. } \\ & \text { become.PST-E }\end{aligned}$

'Mariam tells me that when she was speaking on the phone suddenly the sound was cut' (Jahani 2000: 203).

The situation in Gilaki is comparable to Persian, but not identical. In Gilaki, past and perfect are said to have coalesced (Stilo 2001: 665), the one form being built analogous to the colloquial Persian perfect: the third person singular always looks like the past participle. ${ }^{12}$ Thus, as already exemplified above, the alleged personal ending - $\partial$ only occurs when the past participle of the corresponding verb also ends in - $\partial$. When the past participle ends in a vowel, no personal ending is present. In exchange, the latter can take the quotative marker (as every other verb form), but the former cannot - recall examples (14) and (15). It seems almost too obvious that in order to disentangle this irregularity, -ə simply should not be analyzed as third person singular of the past, but as quotative marker only. Then, there would not be this "special case" any more, i.e., a personal ending that prevents the quotative marker from being added. If this really was the case, both Rastorgueva et al. (1971) and Stilo (2001) would be wrong in presenting - $\partial$ as personal ending. This assumption is, surprisingly enough, further sustained by some instances in the corpus where the third person singular of the past actually does not have an ending. Consider the following two representative examples:

$\begin{array}{lllll}\text { man yeho } & \text { mi } & \text { xun } & \text { vasoxt. } \\ \text { 1SG suddenly } & \text { 1SG.Poss } & \text { blood } & \text { steam.PST:3SG } \\ \text { 'Suddenly I boiled with rage } & \text { (lit. my blood steamed)'. }\end{array}$

(20) Minå harf-a guš bu-kud. Mina word-oBJ ear TAM-make.PST:3SG

'He listened to Mina's words'.

12 Admittedly, they only "look" the same. The proper participle is stressed on the last syllable (-ə), whereas the past on the penultimate, i.e., the syllable before the personal ending. 
Does this mean that Gilaki still possesses an opposition between perfect (with -ə) and past (without -a)? And is one of the functions of the perfect to mark quotatives? The answer has to be no, the main reason being the overwhelming majority of the forms with -ə, also in contexts where no meaning of a perfect fits:

$\begin{array}{lll}\text { dar jå bu-froxt-a, } & \text { åre. } \\ \text { in place } & \text { TAM-sell.PST-3SG } & \text { yes } \\ \text { 'He sold [it] right away, yes'. } & \end{array}$

Still, the $\varnothing$-endings occur, even though they are not very numerous. Their existence could be explained as a structural borrowing from Persian, when a speaker sometimes "erroneously" switches to a somewhat more Persian style. This is fairly possible, as Gilaki underwent and is still undergoing (nowadays more than ever) heavy Persian influence. Nevertheless, further elicitation also showed that informants can accept both forms with and without -ə in almost every case (whatever reason this may have), except for the following example:

\section{(22) šåh bə-kəft! \\ king TAM-fall.PST:3SG \\ 'The king has fallen!'}

When somebody directly observes that the king falls and then comments this with surprise, the ending -ə is apparently not possible and consequently rejected by informants. This use could be regarded as the extreme opposite pole to the quotative marker - $\partial$, which in a broad sense expresses indirect evidence; when -ə is missing, you signal that you have in contrast some very direct evidence, and consequently, you can confirm the information with certainty. Examples (19) and (20) are not direct comments to an incident, but they have in common with (22) that they also express surprise or suddenness and the speaker wants to confirm the surprising news.

Whatever the correct explanation for all these examples is, it seems quite sure that there is a connection between the -a of the past participle, the personal ending, and the quotative marker. Based on the description above, they are most probably cognates in both Gilaki and Persian. The situation in the two languages is comparable as far as the assumed origin of the morpheme is concerned, but the actual use (or so to speak, the grammaticalization) is not the same. Recall that in colloquial Persian the original ending - $e$ of the past participle (used in the perfect) has spread to some other verb forms to express evidentiality. This, however, is limited to verbs built with a past stem and the third person singular. If the development in Gilaki had been the same, one would expect -a to appear in 
the same places. But - $\partial$ became completely detached from the past participle and is suffixed to the right of the personal ending so that the quotative marker occurs in all existing tenses and persons. Thus, the connection between the participial -a and the quotative marker - $\partial$ is not as tight (anymore) as between the corresponding elements in Persian. The personal ending, too, developed away from the past participle, as it carries no stress like all the other personal endings of the past, the participle being stressed on - $\partial$.

However, my proposition is only one possibility. I find it rather difficult to determine the exact path of grammaticalization of the quotative marker. Did it develop internally in Gilaki more or less analogous to Persian but much further grammaticalized? Or, alternatively, did language contact play a role and the quotative marker is a borrowing or calque? And if so, where from? Maybe from a language of the Caucasus, where quotations are usually also marked? Unless more data are available, the possible answers remain highly speculative.

\section{Conclusion}

Gilaki, or at least the Western Gilaki dialect of Rasht, possesses a quotative marker -ə, which is suffixed to (principally) all verbs of a quotation. The quotations are mostly, but not necessarily, introduced by goftan 'say' and the subordinator ke; it is also possible to quote someone without announcing this, as the quotative marker always assures that the utterance is conceived as a quotation.

Quotations correspond most of the time to reported speech, or from another point of view, to report speech quotations are used. Note that reported speech is not the same as indirect speech. As quotations are always direct, reported speech in Gilaki is direct (following a general tendency of the languages in and around Iran to report directly). Indirect speech might be possible, but it is not necessary: due to the fact that there is a quotative marker, Gilaki has a convenient means to report speech.

The use of quotations is somewhat wider than just reporting an utterance of somebody else. They also apply in utterances that have not been said (yet). Furthermore, you can even express the (assumed) thoughts or intentions of somebody else using quotations. Finally, -ə is occasionally also found after verbs of cognition in general.

Quotations do not entail an adaptation of the deictic elements (especially pronouns) to the actual speech situation. Thus, when saying man 'I' the speaker does not point to himself and $t u$ 'you' does not mean the person spoken to. In order to avoid this peculiar situation, the first person singular pronouns man 'I' and $m i$ 'my' are sometimes replaced with the logophoric pronoun $x u$ 'self'. 
In the third person singular of the past, it is not possible to add the quotative marker when the personal ending - $\partial$ is already present. The solution for this anomaly could be found in a shared origin of both -ə: the ending of the past participle.

\section{Abbreviations}

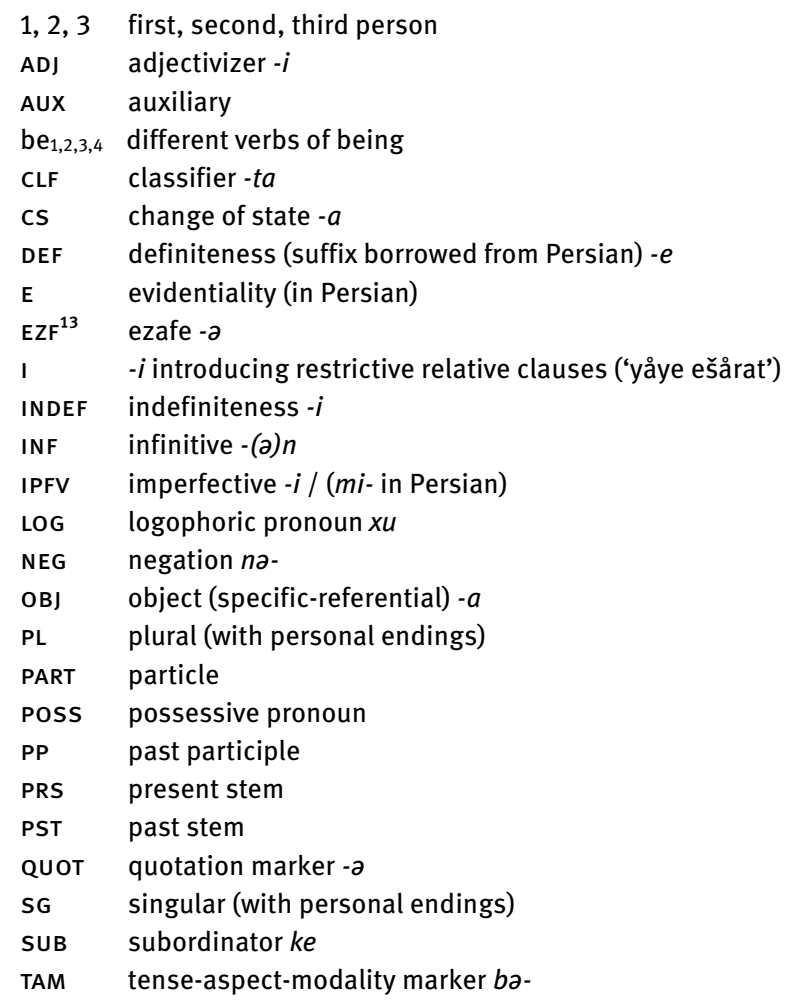

\section{References}

Akin, S. 2002. Discours rapporté et hétérogénéité discoursive en kurde. In L. Rosier (ed.), Le discours rapporté. Faits des Langues 19. Paris: Ophrys. 71-84.

13 Both the dependent-marking ("Gilaki-type") and the head-marking ("Persian-type") ezafe are glossed EZF. In Gilaki both types occur. 
Alavi, B. and M. Lorenz. 1994. Lehrbuch der persischen Sprache. Leipzig: Langenscheidt. Coulmas, F. 1986. Reported speech: Some general issues. In F. Coulmas (ed.), Direct and indirect speech. Berlin: Mouton de Gruyter. 1-28.

Hewitt, B.G. and S. R. Crisp. 1986. Speech reporting in the Caucasus. In F. Coulmas (ed.), Direct and indirect speech. Berlin: Mouton de Gruyter. 121-143.

Jahani, C. 2000. Expressions of Indirectivity in spoken Modern Persian. In L. Johanson and B. Utas (eds.), Evidentials. Berlin and New York: Mouton de Gruyter. 185-207.

Pakpour, P. 2015. Identity construction. The case of young women in Rasht. Studia Iranica Upsaliensia 27. Uppsala: Acta Universitatis Upsaliensis.

Rastorgueva, V. S., A. A. Kerimova, A. K. Mamedzade, L. A. Pireiko, and D. I. Edel'man. 1971. Giljanski jazyk. Moskow: Izdatel'stvo "Nauka".

Sartippur, J. 1990. Vižegihå-ye dasturi va farhang-e våžehå-ye Gilaki. Rasht: Našr-e Gilakån.

Stilo, D. 2001. Gīlān, X. Languages. In E. Yarshater (ed.), Encyclopædia Iranica, vol. X

(Fisheries-Gindaros). New York: Bibliotheca Persica Press. 660-668. 